\title{
Access and its contribution to achieving trust and satisfaction in inter-ethnic relationships
}

\author{
Mensur Zeqiri \\ Faculty of Social Sciences, University of Ljubljana, Ljubljana, Slovenia
}

\begin{abstract}
Purpose - This study seeks to provide further testing of access in the context of government - community relations within the political context of the Republic of North Macedonia. The study analyses relationship cultivation strategy of access and explains how it contributes to achieving trust and relationship satisfaction in government-community relations. This paper also provides insights into the importance of access to achieving positive government-community relations based on mutual trust and satisfaction.

Design/methodology/approach - For this research, a qualitative inquiry was conducted, and qualitative in-depth interviewing was used as the main research method. In total, 39 interviews were conducted: 12 interviews with Macedonian civil servants, eight interviews with Albanian civil servants and 19 interviews with Albanians.

Findings - The findings of this study showed citizens not to have enough access to government and its institutions. Besides, the results showed access to be crucial to building positive government-community relations based on mutual trust and satisfaction. In particular, discrimination and social distance were crucial in building trust between government and citizens.

Originality/value - The study provided evidence on the importance and contribution of the cultivation strategy of access to government-community relationships in general and to the relational outcomes of trust and satisfaction in particular. The findings supported the initial assumptions that access constitutes an important factor in predicting the government-community relationship quality.
\end{abstract}

Keywords Satisfaction, Relationship management, Communication management, Trust, Public relations Paper type Research paper

\section{Introduction}

Public relations as an applied communication science discipline has developed in the past 30 years from predominantly persuasive, mass communication focused area of research into study of communication and relationships at all levels, from intraorganizational to societal. Public relations scholars have come to believe that the fundamental goal of public relations is to build and then enhance ongoing or long-term relationships with an organization's key constituencies (Hon and Grunig, 1999).

In the last two decades, "relationship" and the relational perspective of public relations has dominated academic, public relations research. In developing the theoretical framework, the study followed the relational perspective that views public relations as a management function that helps establish and maintain mutually beneficial relationships. In particular, the study explored Grunig and Huang (2000) concepts of relationship cultivation and relationship outcomes.

Cultivation strategies cover the strategies used to build and sustain quality organizationpublic relationships (Grunig and Huang, 2000). From the six relationship cultivation

(C) Mensur Zeqiri. Published by Emerald Publishing Limited. This article is published under the Creative Commons Attribution (CC BY 4.0) licence. Anyone may reproduce, distribute, translate and create derivative works of this article (for both commercial and non-commercial purposes), subject to full attribution to the original publication and authors. The full terms of this licence may be seen at http:// creativecommons.org/licences/by/4.0/legalcode
Access and trust and satisfaction

Received 16 January 2020

Revised 4 August 2020 Accepted 15 September 2020 
CCIJ

26,1

206

strategies (Grunig and Huang, 2000) that organizations can use to build and maintain the relationships with the various publics (access, positivity, openness, assurances, shared tasks and networking) the study aimed at exploring only the relationship cultivation strategy of access. Access entails the willingness of both parties in a relationship to directly address complaints and questions to each other without discussing it with a third party (Hon and Grunig, 1999). In organization-public relationships, access is considered a strategy that two parties use to reach each other to express or share opinions and thoughts; organizations mainly put their efforts into providing communication channels or media outlets that assist its strategic publics in reaching it (Ki and Hon, 2009).

In addition to the relationship cultivation strategies, the relational perspective of public relations has also identified relationship outcomes that represent relationship quality or the consequences of effective relationship cultivation strategies (Grunig and Huang, 2000). Hon and Grunig (1999) identified four relationship outcomes: trust, commitment, satisfaction and control mutuality. These outcomes are considered to be the essential indicators and dimensions representing the quality of organization-public relationships. From the four identified relationship outcomes, this study focused only on trust and satisfaction.

Scholars (Hon and Grunig, 1999; Grunig and Huang, 2000) contend that several relationship cultivation strategies (e.g. access, positivity, openness, sharing of tasks, networking and assurances) can produce better relationship quality outcomes (e.g. control mutuality, satisfaction, trust and commitment). This shows that cultivation strategies are not to the same extent successful when applied to different organization-public relationships settings. Some cultivation strategies might be successful in managing university-student relationship but might not be to the same extent successful when managing government-community relationships. Furthermore, some relationship strategies compared to others have the most impact on relationship quality outcomes.

As public relations scholarship continues to theorize about and test the effects of relationship cultivation strategies on relationship quality outcomes, the study intended to explore access and explain how it contributes to achieving trust and relationship satisfaction in government-community relations. Using qualitative in-depth interviews, the aim of the study was to uncover more details of the nature of the relationship between the government and Albanians in the Republic of North Macedonia. In particular, the study sought to explore and understand how the parties in the relationship, government and Albanians evaluate government on the cultivation strategy of access. Thus, based on narrations from participants the aim was to understand if both the government and Albanians perceive and evaluate positively or negatively that Albanians have access to the government. Additionally, the study considered access to be important factor influencing trust and satisfaction as relationship outcomes determining the quality of the relationship between government and Albanians. Therefore, the study also focused on the ways access contributes to achieving trust and satisfaction in the relationship between government and Albanians in North Macedonia.

\section{Literature review}

In the past 30 years, public relations has moved from a predominantly persuasive, mass communication focused area of research toward a focus on building and maintaining mutually beneficial relationships between organizations and their publics. The call for focusing on relationships in public relations dates back to Ferguson in 1984. Ferguson (1984) warned that relationships, "not. . the organization, nor the public, nor the communication process," should be the unifying concept of public relations. Since then, the relationship between an organization and publics has been explored as a unit of study by public relations scholarship (Broom et al., 1997; Huang, 1997, 2001; Ledingham and Bruning, 1998; Hon and Grunig, 1999; Bruning and Ledingham, 1999; Grunig and Huang, 2000; Ledingham, 2001). 
In addition, public relations scholarship has identified strategies in which organizations can engage to cultivate relationships with public and outcomes that measure the quality of relationship between organizations and public. Huang (1997) identified trust, control mutuality, relational commitment and relational satisfaction as relationship indicators. Hon and Grunig (1999) provided guidelines for measuring organization-public relationships and identified the following six relationship indicators: control mutuality, trust, commitment, satisfaction, communal relationships and exchange relationships.

Grunig and Huang (2000) developed a theory of organization-public relationships and provided methods for evaluating relationships in each stage: relationship antecedents, cultivation strategies and relationship outcomes. They proposed several relationship cultivation strategies, namely, access, positivity, openness, assurances of legitimacy, networking and sharing of tasks and relationship quality outcome dimensions, namely, trust, commitment, satisfaction and control mutuality. Ki and Hon (2009) developed measures to help public relations professionals better understand how to nurture and sustain relationships with their target publics. In addition, they developed a multiple-item scale meeting the standards of reliability and validity in measurement for measuring relationship cultivation strategies.

Moreover, the relational perspective and models proposed by Hon and Grunig(1999) and Grunig and Huang (2000) have been applied by public relations scholars to explore organization-public relationships in different settings: university-student relationship (Hon and Brunner, 2002; Ki and Hon, 2006), manufacturer-retailer relationship (Jo, 2006), municipal utility-community relationship (Hall, 2006); nonprofit-donor relationship (Waters, 2007; O'Neil, 2007); political party-public relationships (Seltzer and Zhang, 2010) and local government-citizen relationships (Graham, 2014). Studies have also used relational perspective to evaluate employee-organization relationships (Shen, 2011; Men and Stacks, 2014; Seltzer et al., 2012).

Shen (2011) explored how organizations build and maintain relationships with internal public and developed a valid and reliable instrument to measure relationship maintenance strategies in the context of organization-employee relationships. Men and Stacks (2014) studied the effects of authentic leadership on strategic internal communication and employee-organizations relationships. Other studies have explored relationship cultivation and public relations practices in start-up companies (Men et al., 2017); relationship cultivation in public diplomacy with a special focus on the process of initiating, nurturing positive and recovering from negative relationships between various public diplomacy actors (Storie, 2017) and nonprofit relationship management (Pressgrove and McKeever, 2016).

Relationship management in the online environment has been the focus of most of the recent relationship management studies. Men et al. (2017) examined how public positive and negative social media (i.e. WeChat) discussion about President Xi Jinping in China influence public's evaluation of his leadership effectiveness, which in turn, influences public trust and satisfaction with the government. Other studies have studied how digital interaction affects the political organization-public relationship (Sweetser et al., 2015); how inauthentic communication undermines the authenticity and trust within online organization-public relationships (Sisson, 2017a) and what is the role of control mutuality in social media engagement to provide insight into social media strategy creation for nonprofit organizations (Sisson, 2017b).

The relationship between government and citizens is an area of organization-public relationship research that has received little scholarly attention. The first study extending the relational theory of public relations to government-community relationships was conducted by Ledingham (2001). This study focused on explaining if public relations functions as community builder and testing the ability of the relationship scale to predict public behavior. Other government-community relations studies have explored the relationship between local
Access and trust and satisfaction 
CCIJ

26,1

208

governments and the citizens with a particular focus on public relations activities and tactics employed to cultivate relationship (Graham, 2014); democracy and government public relations (Waymer, 2013) and the use of the internet in managing government-public relationships (Hong, 2013, 2014).

Research (Hon and Grunig, 1999; Grunig and Huang, 2000) shows that relationship cultivation strategies are not to the same extent successful to build organization-public relationships. Some relationship cultivation strategies (e.g. access, positivity, openness, sharing of tasks, networking and assurances) can produce better relationship quality outcomes (e.g. control mutuality, satisfaction, trust and commitment). For example, Waters (2007) in studying relationship between non-profit organizations and donors found out that every relationship cultivation strategy, except reciprocity, had a direct influence on evaluation of the relationship dimensions. He found out that access, networking, responsibility and relationship nurturing all significantly affected trust, control mutuality, satisfaction and commitment. Sharing of tasks had a significant impact on trust, and openness significantly influenced satisfaction.

However, as can be seen from the literature reviewed, no single study has focused on studying single relationship cultivation strategies and how they help achieve relationship quality outcomes. Likewise, following Hung's (2007) suggestions that research in the future should move from concentrating on relationship outcomes to relationship cultivation strategies; i.e. how to sustain and cultivate quality relationships with a focus on which relationship cultivation strategies, namely, access, positivity, openness, assurances of legitimacy, networking and sharing of tasks can achieve the relationship qualities, such as trust, control mutuality, commitment and satisfaction, the study was designed to contribute to filling that void as well. This lead to the main objective of the study to understand and explore access and how it contributes to trust and satisfaction between government and community.

\section{Relationship cultivation}

The concept of relationship cultivation describes the way organizations communicate with public and how they manage conflicts to build positive relationships or restore damaged relationships (Grunig and Huang, 2000). Relationship cultivation strategies are the strategies used to maintain relationships with public. Grunig (2002) defined cultivation strategies as "the communication methods that public relations people use to develop new relationships with publics and to deal with the stresses and conflicts that occur in all relationships" (p. 5).

Hon and Grunig (1999) and Grunig and Huang (2000) conceptualized six relationship cultivation strategies that organizations can use to build and maintain the relationships with the various community/public: access, positivity, openness, assurances, shared tasks and networking. Access is the relationship cultivation strategy that this study explores.

\section{Access}

Hon and Grunig (1999) asserted that the use of access in organization-public relationships entails the willingness of both parties to directly address complaints and questions to each other without discussing it with a third party. Ki and Hon (2009) also considered access a strategy that two parties use to reach each other to express or share opinions and thoughts. Based on Hon and Grunig guidelines, they defined access as "the degree of effort that an organization puts into providing communication channels or media outlets that assist its strategic publics in reaching it" (p. 6).

Access entails contact between the organization and the public being it in person, on the phone, via e-mail or on the internet willing to answer questions and responds to concerns of 
the other. The opportunity provided to both parties to meet each other helps voices and concerns of both parties to be heard and later applied when the organization needs to make decisions about future issues (Williams and Brunner, 2010). The questions developed to evaluate access aimed at understanding how much access is given to Albanians by the government. The aim was to understand what kind of contact information is provided to Albanians, how adequate they thought this contact method was, how easy they thought it was to meet a civil servant or someone higher in the hierarchy and how do Albanians usually address their questions and concerns to civil servants.

\section{Relationship outcomes}

Relationship outcomes represent relationship quality or the consequences of effective relationship cultivation strategies. Grunig and Huang (2000) contended that the following four outcomes are the essential indicators and dimensions representing the quality of organization-public relationships: trust, commitment, satisfaction and control mutuality. The study is limited only to the contribution of access to the relationship dimensions of trust and satisfaction.

\section{Trust}

Trust has been viewed as fundamental in understanding the organization-public relationship. Verčič and Grunig (2000) went further and concluded that without trust an organization could not exist. Besides, trust or the lack thereof has a measurable impact on the financial health of an organization (Paine, 2003). Trust is required by stockholders, employees, consumers, governments and communities. Without trust, stockholders will not buy stock, employees will not work, consumers will not buy products and governments will interfere with an organization's mission (Grunig and Huang, 2000).

In public relations literature, Grunig and Grunig (1998) defined trust as "the extent to which both management and publics express willingness to make themselves vulnerable to the behavior of the other - confidence that the other party will take its interests into account in making decisions" (p. 4).

Trust in government or political trust is mainly studied in political science research. Political trust is considered "a central indicator of public's underlying feeling about its polity" (Newton and Norris, 2000, p. 53). Miller and Listhaug (1990) defined political trust as the "judgment of the citizenry that the system and the political incumbents are responsive, and will do what is right even in the absence of constant scrutiny" (p. 358).

In public relations, research trust is considered a complicated concept with several underlying dimensions (Hon and Grunig, 1999; Welch, 2006). Hon and Grunig (1999) have identified three dimensions to measure trust scale: (1) integrity, the belief that an organization is fair and just; (2) dependability, the belief that an organization will do what it says it will do and (3) competence, the belief that an organization has the ability to do what it says it will do.

\section{Satisfaction}

Relational satisfaction has been widely acknowledged as a crucial attribute of relationship quality (Ferguson, 1984; Grunig and Huang, 2000). Grunig and Huang (2000) held that "unlike control mutuality and trust, which involve cognitive dimensions, satisfaction encompasses affection and emotion" (p. 45).

Hon and Grunig (1999) noted that "a satisfying relationship is one in which the benefits outweigh the costs" (p. 3). They further defined satisfaction as "the extent to which one party feels favorably toward the other because positive expectations about the relationship are reinforced" (p. 20).
Access and trust and satisfaction 
CCIJ

26,1

210

\section{Intern-ethnic relations in North Macedonia}

The political context of the Republic of North Macedonia, in particular government-Albanian community relations constitute a relevant case to study access and its contributions to government-community relations. First of all, inter-ethnic tensions have characterized the Republic of North Macedonia since the day it declared independence in 1991. From the very beginning, Albanians living in the Republic of North Macedonia contested different elements of the first constitution, census-taking methods, different laws on education, use of language and national minority symbols, local self-government as well as participation in the police, army and public administration. This perceived political and economic discrimination of Albanians led to a six-month armed confrontation that ended in August 2001 when under close monitoring of the international political factors the parties in conflict signed the Ohrid Framework Agreement.

The Ohrid Framework Agreement guaranteed the right of Albanians of equal representation in the government. Under the Ohrid Framework Agreement, the government was obliged to increase the number of Albanian civil servants to reflect their actual proportion of the country's population. From the latest report published in 2017 by the Ministry of Information Society and Administration, from 110.311 civil servants, 82.900 or $75.15 \%$ are Macedonians, 21.279 or $19.29 \%$ are Albanians and the rest belong to other minority groups (Ministry of Information Society and Administration, 2017). According to the last census of 2002, the Republic of North Macedonia has a population of 2.022.547, out of which Macedonians comprise $64.2 \%$ and Albanians 25.2\% (State Statistical Office, 2002).

Moreover, the government's role, efforts and strategies implemented after the conflict in 2001 have been crucial to foster better inter-ethnic relations between Albanians and Macedonians in the Republic of North Macedonia. The relationship of the government with different ethnic groups has been considered also essential in fostering better inter-ethnic dialog. Thus, government's role is considered fundamental in developing strategies and implementing mechanisms to restore trust in the government and nurture positive relationships with different ethnic communities.

Taking into consideration the improved political position of Albanians in North Macedonia and their increased representation in the government, the study assumed also that now Albanians have more access in the government as well. In line with this, the study assumed more positive relationship now exists between government and Albanians in North Macedonia. Having these in mind, government-Albanian community relations in North Macedonia deemed a relevant case to study access and the ways it fosters better government-community relations.

\section{Research questions}

The research questions developed sought to explore and understand how the parties in the relationship, government, and Albanians, evaluate government on the cultivation strategy of access. The main objective is to explore access and explain the ways it contributes to achieving trust and relationship satisfaction in government-community relations. Likewise, using qualitative in-depth interviews, the study aims to uncover more details of the nature of the relationship between the government and Albanians in the Republic of North Macedonia and to get more insights and detailed answers from the government and Albanians regarding the level of access given to Albanians and how access leads to positive relationships based on mutual trust and satisfaction.

The following research questions guided this study:

$R Q 1$. What is the level of access in the relationship according to the government and the level of access according to Albanians? 


\section{Research methods}

For this research, a qualitative inquiry was conducted, and qualitative in-depth interviewing was used as the main research method. The foci of the research guided the in-depth interviews. Following Grunig's (2002) suggestions that relationships cannot always be reduced to a few fixed-response items on a questionnaire, qualitative in-depth interviews were deemed more suitable to study holistically and into more details the nature of the relationship between government and Albanians in the Republic of North Macedonia and to get more insights and detailed answers from members of public and government on how they perceive this relationship and why they do so.

The interview protocol consisted of open-ended questions. The questions related to access were adjusted from Hon and Grunig (1999) and Ki and Hon (2009) studies that developed quantitative measures of relationship cultivation strategies. The qualitative questions were developed to reflect the same dimensions and operational definitions of the relationship dimensions as the quantitative questions. Only the qualitative questions related to trust and satisfaction were taken from Grunig's (2002) qualitative methods for assessing relationships between organizations and publics.

Qualitative questions about access were developed to evaluate the level of access given to Albanians by the government. The aim was to understand what kind of contact information is provided to Albanians, how adequate they thought this contact method was, how easy they thought it was to meet a civil servant or someone higher in the hierarchy and how do Albanians usually address their questions and concerns to civil servants. Likewise, access was operationalized in terms of the variety of contact information provided to Albanians to contact government civil servants, adequacy of these contact information, the ease with which Albanians can get in touch with civil servants, the methods available to address questions and concerns to civil servants and the willingness of civil servants to reply to questions and concerns posed by the citizens.

To assess trust, respondents were asked to describe actions and decisions taken by the government that has treated Albanians fairly and justly or unfairly and unjustly. Additionally, they were asked to describe what the government has done that indicates they can be relied on to keep their promises. To assess government's competence, respondents were asked how confident they are that government has the ability to accomplish what they say they will do. The questions on trust ended with a general question on how much they trust the government and why do they trust or not trust the government. The questions about satisfaction focused on how satisfied are Albanians with civil servants' professionalism, competence and courtesy/politeness, how much Albanians enjoy dealing and interacting with civil servants and how satisfied and happy Albanians are with the government and the relationship that they have had with the government.

In total, 39 interviews were conducted, 12 interviews with Macedonian civil servants, eight interviews with Albanian civil servants and 19 interviews with Albanians. Albanian civil servants are the civil servants of Albanian ethnicity employed in public administration in North Macedonia. From the latest report published in 2017 by the Ministry of Information Society and Administration, from 110.311 civil servants, 21.279 or $19.29 \%$ are Albanians. The sample of Albanians consisted of citizens of Albanian ethnicity living in North Macedonia. Regarding Albanians, there were some predefined criteria in recruiting them for the interviews. First, they had to be a minimum of 18 years old. Participants had to be living in the country which means that diaspora was excluded. Participants also should have had recent contact with a civil servant. 
CCIJ

26,1

212

Regarding their demographics, the majority of the participants were male. There were only three females from the total number of 19 Albanian interviewees. With regards to education, only one participant was with elementary school education and two others with high school education. The rest of the participants had already attained bachelor or master degrees in different fields. Regarding their designations, a journalist, NGO activists, students, entrepreneurs of small enterprises, as well as two participants that were unemployed but looking for employment participated in the study.

The recorded interviews were then transcribed into word and archived as well. Even if it was time-consuming, the researcher conducted a verbatim, word-by-word transcription of the interviews. The texts analyzed in the study are from the transcription of in-depth interviews.

Data analysis for the study mainly included interpretive and reflexive reading of the data. Self-understanding, critical common sense understanding and theoretical understanding were employed to interpret and draw conclusions out of the data. Wolcott (1994) suggested that during the interpretation of the data, the researcher goes beyond data and begins to question "what is to be made of them" (p. 36).

During the data analysis, the three interlinked processes suggested by Miles and Huberman (1994) were followed for the study. First, during the data collection process, to reduce the data after each interview, the researcher would listen to the interviews again and enhance them with the notes taken as well as additional comments that he might have missed. Also, interviews were regularly compared to those of previous interviewees to identify significant points and ask the other participants to comment on them.

During the data reduction process, the data were reduced when transcribing the interviews. Although a verbatim transcription of the interviews was done, important data and issues that he noticed during the transcription were highlighted. Because software was used during the transcription, the same software allowed adding comments or memos to the pieces of data that were important and could be used in the later stage of the analysis to display the data and draw conclusions.

However, the data analysis and display were not done manually but using a qualitative data analysis software widely known as CAQDAS (computer-assisted qualitative data analysis software). Atlas.ti was not used to do the analysis but essentially to ease the process of data analysis. As Gibbs (2013) argued, the qualitative data analysis software does not analyze; rather the software mainly helps organize the analysis and manage the data. Atlas.ti was mainly used in the process of transcribing documents, archiving and coding. The software was helpful to code and revise codes easily through the analysis. Although software was used to code, the transcriptions of the interviews would be read over and over again to make sense of the findings, and the passages relevant to the research questions would be highlighted.

\section{Findings}

(1) Access

Overall, the findings showed Albanians not to have enough access to government and its institutions. Regarding the contact information available to Albanians, all sides agreed that direct meetings or meetings through personal connections are the most frequent contact methods used by citizens to contact or make an appointment with a civil servant. Personal connections or referrals was considered to be the most adequate method to contact civil servants. This is understood from the response of an Albanian living in Tetovo who commented that

It depends on your needs and nature of service which method would be most suitable. However, I think that in most of the cases direct meetings are the most preferred contact method, whereas most 
fruitful are suggestions from personal connections. The telephone can help you sometimes, while e-mails are not helpful at all.

However, younger generations of Albanians are not satisfied with direct meetings as the only available method to contact civil servants. They believe that civil servants "should use more telephone and e-mail communication because even for single information we cannot always go to the respective institution". They find it difficult that they must always go to the office even for a simple question or clarification.

Besides, both Macedonian and Albanian civil servants also admitted that direct meetings are their preferred and widely used method of contact with Albanians. A Macedonian civil servant explained that "in the Republic of North Macedonia we still use private or personal connections, which in my opinion is not good. Citizens can use telephone or e-mail, but these are not adequate. Citizens mainly use personal connections, friends, and political party connections to make an appointment as soon as possible."

With regard to the ease with which Albanians can get in touch with civil servants, interviews uncovered that in North Macedonia it is quite easy to meet civil servants. An Albanian illustrated in details how meetings with civil servants take place.

Civil servants of the lowest level of public administration are quite easy to meet. I have myself many times gone directly to the institution and have never had problems meeting them. Anyways, there are no appointments needed; you have to always respect waiting lines in front of the door.

Civil servants, both Albanians and Macedonians also admit that it is quite easy for citizens to meet them. They also contended that meetings normally take place in their office, and "if there is no waiting line, you simple knock on the door and we are here always available for them." Macedonian civil servants considered language to be an obstacle in their meeting because "Albanians, especially younger generation do speak poorly Macedonian language. I do not speak Albanian. We really have difficulties in communication."

Findings showed Macedonian and Albanian civil servants to disagree about meeting civil servants higher in the hierarchy. Macedonian civil servants considered that it is easy to meet civil servants higher in the hierarchy if proper formal procedures were followed. They also confessed that personal connections, especially connections within the political party in position ease the way to civil servants higher in the hierarchy. On the other side, Albanian civil servants considered meeting civil servants higher in the hierarchy to be quite difficult or impossible without using personal connections. A civil servant confessed that they "as civil servants have difficulties meeting them, now imagine how easy it can be for citizens." Albanians also think that it is impossible to meet civil servants higher in the hierarchy without personal connections. This citizen considered that "in the Republic of North Macedonia is quite important to use personal connections, or better to say it is necessary. However, using personal connections within the political parties in position is the best way to get to officials higher in the hierarchy..."

Regarding the methods Albanians use to address their concerns and problems, all participants agreed that Albanians mainly address their complaints personally in the institution or through personal connections, mainly via their contacts in the political party in position. Both Macedonian and Albanian civil servants think that they are willing to help Albanians. However, they point out that they also have limited jurisdictions which hinder them from helping Albanians and can be perceived as they are not willing to help Albanians. Macedonian and Albanian civil servants are aware that Albanians do not believe that they are willing to consider their concerns. Albanians are convinced that their complaints and concerns are not considered which makes them avoid official procedures to address them and mainly revert to personal connections. This participant all the questions and concerns he has addresses them "directly in the institution because there are huge communication difficulties
Access and trust and satisfaction 
CCIJ

26,1

214

between citizens and government institutions. The first thing that you feel when you address your concerns is pessimism because even before you contact them you have no hope that your concerns will be considered. They will always find useless justifications to get rid of you, instead of getting your problems considered or solved."

As described by an Albanian participant "civil servants are never willing to help; this is only something you can dream of in the Republic of North Macedonia. You really need to pressure them in order to successfully accomplish something." Albanians also reported that civil servants in some cases are arrogant and portray bossy attitude toward citizens.

(2) Trust

Albanians, in general, answered that they do not trust at all the government. Most of the participants started their answers with the phrase "I do not trust government at all." This citizen when asked how much he trusts government answered that he "do not trust government at all. Everything that you do in life, all the steps that you take, government is always an obstacle and not a facilitator. This shows how much government supports and is close to citizens."

Albanian civil servants also believed that Albanians do not trust government at all. This civil servant claimed that "They do not trust government at all, starting from myself as well. What we also hear from citizens, they do not trust government ..." However, the majority of Macedonian civil servants thought that the majority of Albanians trusted the government although there can be people that do not trust. As this participant believed evaluation of trust "depends most probably from citizen's personal experiences and political convictions and affiliations."

Considering integrity, both Albanians and Albanian civil servants think that Albanians are treated unfairly and unjustly. An Albanian citizen felt that "as an equal citizen in this country I feel I'm not treated fair and correctly, being it from civil servants or from government in general." Contrary to Albanians and Albanian civil servants, Macedonian civil servants thought that after the Ohrid framework agreement "Albanians have improved their rights and conditions, state university, proportional employment, institutional use of Albanian language, etc. Thus I think that they are treated fairly and correctly like all other citizens."

Both Albanians and Albanian civil servants agreed that government and government institutions cannot be relied on to keep promises because there is huge promise-achievement discrepancy. According to a participant "usually they promise a lot and only a quite small percentage of it can be achieved..." In general, Macedonian civil servants think that Albanians can rely on government to keep promises. There were Macedonian civil servants that could confirm and ensure that "all promises are met without any exception."

With regard to competence, the majority of Albanians thought that the government has no capacity to accomplish what they say they will. According to them, it is lack of meritocracy and unprofessionalism that government institutions lack. Also, Albanians believed that "usually compared to their capacity they promise much more than they can do." On the other side, same like their Albanian colleagues, Macedonian civil servants also think that capacity exists; however they lack willingness and desire to govern responsibly for the good of the society. This Macedonian civil servant considers that "capacity honestly exists, however will for improvement and successful governance is missing."

(3) Satisfaction

Albanians, in general, are not satisfied with knowledgeability, politeness and professionalism of civil servants. The majority of participants found civil servants quite arrogant. Albanians also think that due to unprofessional and highly politicized public administration citizens are 
not able to receive service quality. This participant described from his experience that "very little of civil servants have been competent, knowledgeable, polite and professional." Albanians also admitted that they do not enjoy dealing with civil servants. They claimed not to be satisfied with their communication with civil servants. Albanians also think that majority of civil servants, "lack elementary communication behavior. They do not know how to formally communicate and interact with citizens." Albanians admitted they are not happy with the government, and they claimed that they are also not satisfied with the relationship that the government has had with them. This participant described in details why he is not satisfied with government:

I am not at all happy with government. I consider it an anti-citizen government in general and an antiAlbanian government in particular because there are lots of cases of discrimination, for example ethnical discrimination, discrimination in budget allocations, increase of dissatisfaction and massive migration among Albanians, discrimination in every aspect, inequality, etc.

Albanian civil servants did share the same opinion with the Albanians regarding their overall satisfaction with the government. All of them believed that the Albanians are not at all satisfied with government. Albanian civil servants also admitted that Albanians are not satisfied with the knowledgeability, politeness and professionalism of civil servants. However, Albanian civil servants thought that Albanians built their perceptions based on a single unsatisfying experience and "they over generalize their experiences, and they always start from the same stereotypes." Albanian civil servants were also self-critical and agreed with Albanians that they rank low on all three dimensions: competence, politeness and professionalism. According to this civil servant, the main reason is "employment and selection of civil servant out of any acceptable criteria and standards and lack or meritocracy."

Macedonian civil servants were of the opposite opinion from Albanians and thought that Albanians were satisfied with the knowledgeability, politeness and professionalism of civil servants. Compared to Albanians, Macedonian civil servants thought that "now in Macedonian there is a highly professionalized public administration." Same as their Albanian colleagues, Macedonian civil servants also admitted that Albanians do not enjoy dealing with civil servants. They also believed that "interaction with civil servants is not meant to enjoy."

Regarding the overall satisfaction of Albanians with the government, Macedonian civil servants were divided in their opinion with a majority of them thinking that Albanians were satisfied with government. There were still Macedonian civil servants that thought that "no one in this country is satisfied with this government. Reasons are numerous, including increased unemployment, inflation, politicization of public institutions, etc." However, the majority of Macedonian civil servants thought that Albanians were satisfied with the government because "after the Ohrid Framework Agreement many things changed positively and their position and influence in the country positively changed. They have ministers in the government, in the public administration they are represented with more than $20 \%$, universities in Albanian language, etc."

\section{Discussion}

The first research question was used to evaluate if civil servants thought access was provided to Albanians and did Albanians perceive they are given access by the government. The findings illustrate that Albanians do not have the desired access to government. In addition, findings reported in previous section also showed that Albanians do not trust government and are not satisfied with the government and the relationship government has had with them. The second research question aimed to understand the ways access 
CCIJ

26,1

contributed to trust and relationship satisfaction which explained in the discussion that follows.

Contributions of access to government-community relations. Overall, when looking for patterns, all participants that evaluated the government low on access, they also evaluated trust and satisfaction to be low. Even among Albanians, those that mentioned access to be a little bit higher, they also evaluated a little bit better trust and satisfaction of Albanians. Additionally, Macedonian civil servants that evaluated government higher on access also answered Albanians to trust and be more satisfied with government. These findings indicated a relationship between access and relationship outcomes of trust and satisfaction in building positive government-community relations.

In addition, the findings show availability of various contact information to be important to provide more access to Albanians which in turn would lead to trust and satisfaction. Citizens are mainly constrained to the use of direct meetings because e-mails and telephone are not functional. To improve access, government should put more efforts to provide additional channels of communications such as e-mails, telephone and social media in their communication with citizens. These channels are also providing the fastest and most convenient way for citizens to get in touch with government institutions. This would help citizens avoid long waiting lines as well as the anxiety they said they felt when they knew they had to deal with civil servants.

Additional contact information would improve citizen service and increase the satisfaction of citizens with the government. In particular, modern internet technologies, email, websites and social media have significantly changed and enhanced communication between government and their citizen clients and would thus contribute to providing more access to Albanians. Use of internet would be helpful in increasing access to government because it helps create a stronger and closer relationship between citizens and government, provides easier access to government for all, improves the level of service to citizens, empowers citizens and provides more transparency in government with more responsibility (Fahnbulleh, 2005).

In addition, the personal influence model (Grunig et al., 1995) is quite common in gaining access and cultivating relationships between government and Albanians in North Macedonia. Citizens revert exclusively to personal connections in contacting civil servants and getting their problems solved. Citizens even mentioned that "without connections or citizens belonging to other political parties are discriminated in obtaining services from public administration." In public relations, practitioners build personal influence with individuals by doing favors for them so they can solicit these favors in return when the organizations need them (Sriramesh et al., 1999). The study showed that Albanians address their complaints personally predominantly via their contacts in the political party in position. Thus, as it was confirmed by some participants, Albanians believed that political parties use these favors they do to citizens to condition them during the elections to win as many votes as possible from the citizens and their relatives.

In addition, limited access to officials higher in the hierarchy leads to perceived social distance which then makes citizens feel they are not being important to civil servants and government. Albanians believed civil servants higher in the hierarchy try to keep distance from citizens to show their superiority and power toward citizens. As this participant explained, social distancing is "a problem inherited from the communist ideology or the remnants of this ideology in country's governance. The bigger the distance between them and citizens, the more powerful they feel; and the closer they get to citizens, the more they feel they lose power or importance."

Although social distance was identified as an obstacle to access, this seems not to be quite important to Albanians in their relationship with government. Being used to social distance, they were more concerned with efficiency and professionalism of public administration. 
Many of them reported that no matter if it is easy or not to meet civil servants, being served properly and getting your job done is highly questionable. A Macedonian civil servant also believed that "if citizens manage to get their job done, they forget their negative experience and interaction they might have had with civil servants." This shows that civil servants should be more friendly and closer to citizens in order to nurture more positive government-public relationships. This would also help citizens get rid of that feeling of contempt, neglection and inferiority they reported to experience when dealing with civil servants. In return they would feel supportiveness, comfort, sympathy, importance and satisfaction.

This would also convey to them the feeling that the government cares about them and their concerns because Albanians think that civil servants are not willing to attend to their inquiries. This makes them feel that the government does not care much about them. This also results in pessimism to address their concerns or inquiries because they have no hopes that their concerns will be considered. This shows that lack of trust and bad experience forced Albanians directly go to the institution because they did not believe that government and civil servants are willing to address or solve their concerns.

Albanians also reported being discriminated with regard to access to government if they have no personal connections. This showed the influence that discrimination based on personal connection has on integrity. Discrimination also makes citizens feel unfairly and unjustly treated. As was confessed by Albanians, they felt contempt when meeting civil servants without personal connections. They claimed to feel overlooked and unimportant because civil servants only try to get rid of them.

\section{Implications}

Findings of this study provide important theoretical implications. The study provided evidence on the importance and contribution of access to government-public relationships in general and to relational outcomes of trust and satisfaction in particular. The findings supported the initial assumptions that access constitutes an important factor in predicting the government-citizen relationship quality. The study also showed that access and the relational outcomes of trust and satisfaction are appropriate and reliable in the government-citizen context. The study has also implications for practice, society and government-community relations. In a multi-ethnic society, the government should plan programs that cater to a broad spectrum of citizens in order not to make minority groups or ethnicities feel discriminated. Citizens should all be treated equally in all government institutions. Public administration services should be equally available to all citizens without exception. Privileges based on political or personal connections should be avoided as it leads to citizen discrimination. The government should provide more communication channels or media outlets that assist its citizens in reaching it. In particular, government should provide adequate contact information and not stick only to direct meetings. In addition, lack of professionalism and politicization of public administration seem to be the main cause of bad citizen service weakening trust and satisfaction with the government. The government should apply meritocracy in employing civil servants to improve citizen service and professionalism in public administration. The government should also make realistic promises and should not promise more than they can achieve. Failure to keep promises deteriorates public trust in government.

\section{Limitations and future research}

Several limitations were identified which could s help guide future research studies. The first major limitation of the study is related to its methodology. The study was only conducted
Access and trust and satisfaction 
CCIJ

26,1

using one methodology, namely, qualitative interviews. Moreover, it is known that interviews yield self-report data. Although in the researcher's opinion, he managed to build a good rapport with his participants, still, the sensitive topic of the research on governmentAlbanian relationships could have affected answers from participants. Future research in studying government-community relations should also include the rest of cultivation strategies as well as the two other relational outcomes, commitment, and control mutuality. This can help provide broader and thorough understanding of the importance and contribution of individual cultivation strategies to relationship quality outcomes.

\section{References}

Broom, G.M., Casey, S. and Ritchey, J. (1997), “Toward a concept and theory of organization-public relationships", Journal of Public Relations Research, Vol. 9 No. 2, pp. 83-98.

Bruning, S.D. and Ledingham, J.A. (1999), "Relationships between organizations and publics: development of a multi-dimensional organization-public relationship scale", Public Relations Review, Vol. 25 No. 2, pp. 157-170.

Fahnbulleh, N. (2005), "The future of electronic government", Futurics, Vol. 29 Nos 1/2, pp. 7-12.

Ferguson, M.A. (1984), "Building theory in public relations: interorganizational relationships as a public relations paradigm”, Paper Presented to the Association for Education in Journalism and Mass Communication, Gainesville, FL.

Gibbs, G.R. (2013), "Using software in qualitative analysis", in Flick, U. (Ed.), The SAGE Handbook of Qualitative Data Analysis, Sage Publications, London, pp. 277-294.

Graham, M.W. (2014), Local Government-Citizen Relationships: Using the Coorientation Approach to Analyze Relationship Effectiveness, $\mathrm{PhD}$ Thesis, University of Tennessee, Knoxville.

Grunig,J.E. (2002), “Qualitative methods for assessing relationships between organizations and publics”, available at: http://www.instituteforpr.org/wp-content/uploads/2002_AssessingRelations.pdf (accessed 16 October 2019).

Grunig, J.E. and Grunig L.A. (1998), "Does evaluation of PR measure the real value of PR?”, Jim and Lauri Grunig's Research: A Supplement of pr Reporter, Vol. 41 No. 35, p. 4.

Grunig, J.E. and Huang, Y. (2000), "From organizational effectiveness to relationship indicators: antecedents of relationships, public relations strategies, and relationship outcomes", in Ledingham, J.A. and Bruning, S.D. (Eds), Public Relations as Relationship Management: A Relational Approach to the Study and Practice of Public Relations, Lawrence Erlbaum Associates, Mahwah, NJ, pp. 23-54.

Grunig, J.E., Grunig, L.A., Sriramesh, K., Huang, Y. and Lyra, A. (1995), "Models of public relations in an international setting", Journal of Public Relations Research, Vol. 7 No. 3, pp. 163-186.

Hall, M.R. (2006), "Corporate philanthropy and corporate community relations: measuring relationship-building results", Journal of Public Relations Research, Vol. 18 No. 1, pp. 1-21, doi: 10.1207/s1532754xjprr1801_1.

Hon, L. and Brunner, B. (2002), "Measuring public relationships among students and administrators at the University of Florida”, Journal of Communication Management, Vol. 6 No. 3, pp. 227-238.

Hon, L. and Grunig, J.E. (1999), "Guidelines for measuring relationships in public relations", available at: https://www.instituteforpr.org/wp-content/uploads/Guidelines_Measuring_Relationships.pdf (accessed 16 October 2019).

Hong, H. (2013), “Government websites and social media's influence on government-public relationships", Public Relations Review, Vol. 39 No. 4, pp. 346-356.

Hong, H. (2014), "The Internet, transparency, and government-public relationships in Seoul, South Korea”, Public Relations Review, Vol. 40 No. 3, pp. 500-502. 
Huang, Y. (1997), Public Relations Strategies, Relational Outcomes, and Conflict Management Strategies, PhD Thesis, University of Maryland, College Park, MD.

Huang, Y. (2001), "OPRA: a cross-cultural, multiple-item scale for measuring organization- public relationships", Journal of Public Relations Research, Vol. 13 No. 1, pp. 61-90.

Hung, C.F. (2007), "Toward the theory of relationship management in public relations: how to cultivate quality relationship?", in Toth, E. (Ed.), The Future of Excellence in Public Relations and Communication Management, Lawrence Erlbaum Associates, Mahwah, NJ, pp. 443-476.

Jo, S. (2006), "Measurement of organization-public relationships: validation of measurement using a manufacturer-retailer relationship", Journal of Public Relations Research, Vol. 18 No. 3, pp. 225-248.

Ki, E. and Hon, L.C. (2006), "Relationship maintenance strategies on Fortune 500 company web sites", Journal of Communication Management, Vol. 10 No. 1, pp. 27-43.

Ki, E. and Hon, L.C. (2009), "A measure of relationship cultivation strategies", Journal of Public Relations Research, Vol. 21 No. 1, pp. 1-24.

Ledingham, J.A. (2001), "Government-community relationships: extending the relational theory of public relations", Public Relations Review, Vol. 27 No. 3, pp. 285-295.

Ledingham, J.A. and Bruning, S.D. (1998), "Relationship management in public relations: dimensions of an organization-public relationship", Public Relations Review, Vol. 24 No. 1, pp. 55-65.

Men, L.R. and Stacks, D. (2014), "The effects of authentic leadership on strategic internal communication and employee-organization relationships", Journal of Public Relations Research, Vol. 26 No. 4, pp. 301-324.

Men, L.R., Ji, Y.G. and Chen, Z.F. (2017), "Dialogues with entrepreneurs in China: how start-up companies cultivate relationships with strategic publics", Journal of Public Relations Research, Vol. 29 No. 2-3, pp. 90-113.

Miles, M.B. and Huberman, A.M. (1994), Qualitative Data Analysis: An Expanded Sourcebook, Sage Publications, Thousand Oaks, CA.

Miller, A.H. and Listhaug, O. (1990), "Political parties and confidence in government: a comparison of Norway, Sweden and the United States", British Journal of Political Science, Vol. 20 No. 3, p. 357.

Ministry of Information Society and Administration. (2017), "Annual report on the data from the public sector employees register for 2017”, available at: http://mioa.gov.mk/sites/default/files/ pbl_files/documents/reports/izvestajreg2017_v1.02.pdf.

Newton, K. and Norris, P. (2000), “Confidence in public institutions: faith, culture, or performance?”, in Pharr, S.J. and Putnam, R.D. (Eds), Disaffected Democracies: What's Troubling the Trilateral Democracies?, Princeton University Press, Princeton, NJ, pp. 52-73.

O'Neil, J. (2007), "The link between strong public relationships and donor support", Public Relations Review, Vol. 33 No. 1, pp. 99-102.

Paine, K.H. (2003), "Guideliness for measuring trust in organizations", available at: https://www. instituteforpr.org/wp-content/uploads/2003_MeasuringTrust.pdf (accessed 16 October 2019).

Pressgrove, G.N. and McKeever, B.W. (2016), "Nonprofit relationship management: extending the organization-public relationship to loyalty and behaviors", Journal of Public Relations Research, Vol. 28 Nos 3-4, pp. 193-211.

Seltzer, T. and Zhang, W. (2010), "Toward a model of political organization-public relationships: antecedent and cultivation strategy influence on citizens relationships with political parties", Journal of Public Relations Research, Vol. 23 No. 1, pp. 24-45.

Seltzer, T., Gardner, E., Bichard, S. and Callison, C. (2012), "PR in the ER: managing internal organization-public relationships in a hospital emergency department”, Public Relations Review, Vol. 38 No. 1, pp. 128-136.

Shen, H. (2011), "Organization-employee relationship maintenance strategies: a new measuring instrument”, Journalism and Mass Communication Quarterly, Vol. 88 No. 2, pp. 398-415.

Access and trust and satisfaction 
CCIJ 26,1

Sisson, D.C. (2017a), "Inauthentic communication, organization-public relationships, and trust: a content analysis of online astroturfing news coverage", Public Relations Review, Vol. 43 No. 4, pp. 788-795.

Sisson, D.C. (2017b), "Control mutuality, social media, and organization-public relationships: a study of local animal welfare organizations' donors”, Public Relations Review, Vol. 43 No. 1, pp. 179-189.

Sriramesh, K., Kim, Y. and Takasaki, M. (1999), "Public relations in three Asian cultures: an analysis", Journal of Public Relations Research, Vol. 11 No. 4, pp. 271-292.

State Statistical Office (2002), "Census of population, households and dwellings in the republic of Macedonia”, available at: http://www.stat.gov.mk/Publikacii/knigaX.pdf (accessed 28 July 2020).

Storie, L.K. (2017), "Relationship cultivation in public diplomacy: a qualitative study of relational antecedents and cultivation strategies", Journal of Public Relations Research, Vol. 29 No. 6, pp. 295-310.

Sweetser, K.D., English, K. and Fernandes, J. (2015), "Super PACs and strong relationships: the impact of digital interaction on the political organization-public relationship", Journal of Public Relations Research, Vol. 27 No. 2, pp. 101-117, doi: 10.1080/1062726x.2014.976824.

Verčič, D. and Grunig, J.E. (2000), "The origins of public relations theory in economics and strategic management”, in Moss, D., Verčič, D. and Warnaby, G. (Eds), Perspectives on Public Relations Research, Routledge, London and New York, pp. 9-58.

Waters, R.D. (2007), Advancing Relationship Management Theory: Coorientation and the NonprofitDonor Relationship, $\mathrm{PhD}$ Thesis, University of Florida, Gainesville.

Waymer, D. (2013), "Democracy and government public relations: expanding the scope of 'Relationship' in public relations research", Public Relations Review, Vol. 39 No. 4, pp. 320-331.

Welch, M. (2006), "Rethinking relationship management: exploring the dimension of trust", Journal of Communication Management, Vol. 10 No. 2, pp. 138-155.

Williams, K.D. and Brunner, B.R. (2010), "Using cultivation strategies to manage public relationships: a content analysis of non-profit organisations' websites”, PRism, Vol. 7 No. 2, available at: http://www.prismjournal.org/fileadmin/Praxis/Files/Journal_Files/Williams_Brunner.pdf (accessed 16 October 2019).

Wolcott, H.F. (1994), Transforming Qualitative Data: Description, Analysis, and Interpretation, Sage Publications, Thousand Oaks, CA.

\section{Corresponding author}

Mensur Zeqiri can be contacted at: mensurzeqiri@gmail.com

For instructions on how to order reprints of this article, please visit our website:

www.emeraldgrouppublishing.com/licensing/reprints.htm

Or contact us for further details: permissions@emeraldinsight.com 